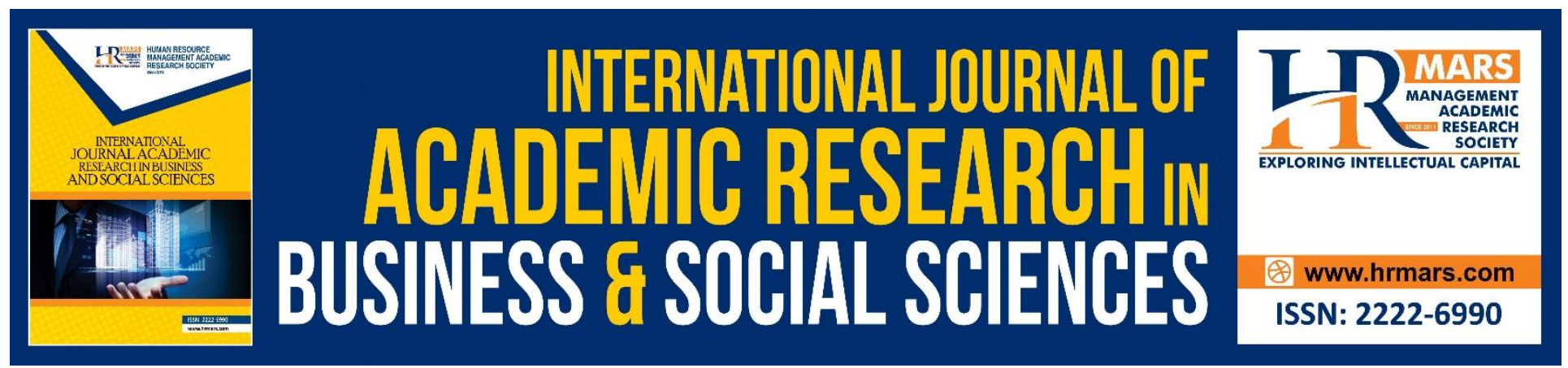

\title{
The Personality of Al-Tabari and his Expertise in The Field of Al-Quran And Qiraat
}

Nor Hafizi bin Yusof, Fatimah Zaharah Binti Ismail, Mohd A'tarahim bin Mohd Razali, Mohd Faiz Hakimi Bin Mat Idris, Ahmad Fauzi Bin Hassan

To Link this Article: http://dx.doi.org/10.6007/IJARBSS/v10-i9/7890

DOI:10.6007/IJARBSS/v10-i9/7890

Received: 12 July 2020, Revised: 04 August 2020, Accepted: 26 August 2020

Published Online: 20 September 2020

In-Text Citation: (Yusof, et.al, 2020)

To Cite this Article: Yusof, N. H. B., Ismail, F. Z. B., Razali, M. A. B. M., Idris, M. F. H. B. M., Hassan, A. F. B. (2020). The Personality of Al-Tabari and his Expertise in The Field of Al-Quran And Qiraat. International Journal of Academic Research in Business and Social Sciences. 10(9), 972-980.

Copyright: (c) 2020 The Author(s)

Published by Human Resource Management Academic Research Society (www.hrmars.com)

This article is published under the Creative Commons Attribution (CC BY 4.0) license. Anyone may reproduce, distribute, translate and create derivative works of this article (for both commercial and non-commercial purposes), subject to full attribution to the original publication and authors. The full terms of this license may be seen at: http://creativecommons.org/licences/by/4.0/legalcode

Vol. 10, No. 9, 2020, Pg. 972 - 980

http://hrmars.com/index.php/pages/detail/IJARBSS

JOURNAL HOMEPAGE

Full Terms \& Conditions of access and use can be found at http://hrmars.com/index.php/pages/detail/publication-ethics 


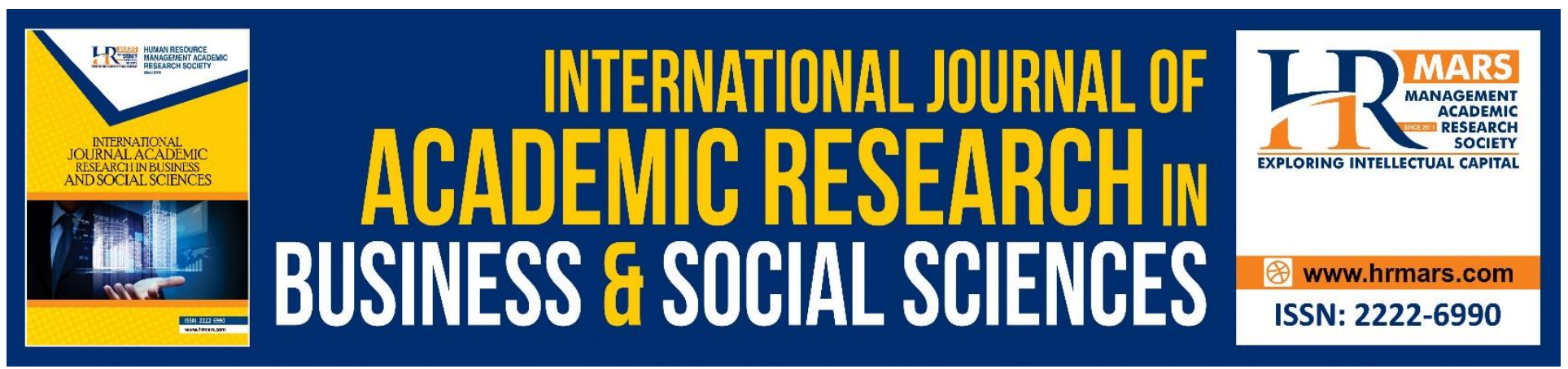

\title{
The Personality of Al-Tabari and his Expertise in The Field of Al-Quran And Qiraat
}

\section{Nor Hafizi bin Yusof, Fatimah Zaharah Binti Ismail, Mohd A'tarahim bin Mohd Razali, Mohd Faiz Hakimi Bin Mat Idris, Ahmad Fauzi Bin Hassan}

Universiti Sultan Zainal Abidin, Terengganu, Malaysia

Email:nhafizi@uniszaedu.my

\begin{abstract}
Imam al-Tabari was a known figure in the Quranic interpretation. He was also an expert in qiraat. This is reflected in his knowledge of qiraat and his style of debating the qiraat in his interpretation of Jami' al-Bayan 'an Ta'wil Ay al-Qur'an. The scholarly discussion of the qiraat in the interpretation had been made by some scholars through the books of Ulum al-Quran and Knowledge of Qiraat. However, during the compilation of the opinions of these figures, al-Tabari's views were not debated in depth although he was known as al-Qurra' as well as a famous mufassir. Therefore, this study aims to investigate the credibility, expertise and contribution of Imam al-Tabari in qiraat and Qur'anic knowledge. This information was collected and analyzed by discussing the scholars' views of him and his writings and beliefs in qiraat. All data were collected through a literature study and analyzed using inductive and deductive methods. The results show that al-Tabari's expertise in qiraat knowledge was evidenced by his narration in qiraat knowledge, the writing of qiraat books and detailed qiraat debates in his interpretations. In conclusion, besides a mufassir, Imam al-Tabari also has his own choice of qiraat (ikhtiyar) and writings in the field of qiraat and deserved to be called a Qiraat scholar (al-Qurra').
\end{abstract}

\section{Introduction}

Imam al-Tabari or his full name Muhammad bin Jarir bin Yazid bin Kathir bin Ghalib, Abu Ja'far alTabari was famous among the Muslim scholars through his excellent writings that were highly ranked in the Islamic studies, especially his commentary on the Quran entitled Jami' al-Bayan 'an Ta' wil Ay al-Qur'an and Tarikh al-Umam wa al-Muluk. Both of the writings are the primary sources in the Islamic studies.

\section{Life}

He was born in Amal, the biggest town in Tabaristan (al-Hamawi, n.d.) in the end of $224 \mathrm{H}$ or early $225 \mathrm{H}$. The dispute on the date was based from his message to his disciple, al-Qadi Ibn Kamil when asked about the date of birth (al-Dhahabi, 1983). It was common among the local that the birth date 
was remembered based on an event that took place when the people of Mizyar bin Qarin rebelled against the caliphate of Muktasim. The war ended with a severe disaster to some 20000 Amal people that were besieged with iron and imprisoned by the Caliph (al-Tabari, 1967).

Imam al-Tabari already showed signs of intelligence since childhood. This was evidenced when he managed to memorize the Qur'an at the age of 7 and was appointed as the prayer leader at the age of 8 . He also began to write the hadith of Rasulullah SAW when he was nine which was an extraordinary ability compared to his peers (al-Hamawi, 1993).

He spent most of his life by devoting himself to knowledge and left home at the age of 12 that he did not have time to think about marriage. He remained single until the end of his life (al-'Asqalani, 2002). Historians recorded his knowledge life as follows (al-Hamawi, 1993)

Imam al-Tabari lived in his house to write books until the time for 'Asr prayer. Then he went out for 'Asr prayer and sat with the people to teach al-Qur'an (talaqqi and tasmi') until the time for Maghrib prayer. He continued teaching Figh and others until 'Isha and entered his home to continue his writing.

He was accustomed to not let people disturb him while he was writing, except for a very important affair. He always busied himself reciting al-Qur'an. According to some histories, he recited a quarter of al-Qur'an every night, or more. Despite his busy life, he entertained wedding invitations or walimah al-'Arusah where his presence was meaningful to the host and the ceremony was considered more noble (al-Hamawi, 1993).

It was narrated that at the moment of his death, a group of his followers had visited and asked for a will and advices about religion. He then replied, "What I do with my religion and my will is what is contained in my books, so act in accordance with it". Then he multiplied the words of shahadah and zikrullah, swept his face and covered the eyes with his hands. He straightened his hands and he had left to meet the Creator (al-Dhahabi, 1983).

Ibn Kathir told that the death of al-Tabari was on a Sunday, the last two days of Syawal $310 \mathrm{H}$ ath the age of 80,85 , or 86 years old. He was buried in his house because there was a group of people from Hanabilah prohibited to bury him during the day. They also accused al-Tabari apostate and in fact some ignorants ascribed him as an atheist. Ibn Kathir defended Imam al-Tabari, denying the allegations and described those who accused as the follower of Abu Bakar Muhammad Ibn Dawud al-Zahiri who once accused al-Tabari as al-'Azaim (the great offender) and apostate. His grave was visited by the public for months to pray for his remain (Ibn Kathir, 2005). According to (Ibn Khallikan ,1993), he died on Saturday and buried on Sunday, 26 Syawal 310H.

\section{Teachers and Students of Al-tabari}

Imam al-Tabari have spent the most of his life to learn and teach. To achieve this goal, he travelled to various ountries such as 'Iraq, Sham, and Egypt. He took every advantage and opportunity to find famous scholars and study various knowledge such as al-Qira'at, al-Hadis, al-Tafsir, al-Figh, alLughah, and al-Adab. Therefore, he had so many teachers. Imam al-Dhahabi in his book Siyar A'lam al-Nubala' quoted from al-Farghani that al-Tabari had authored a book entitle Tarikh al-Rijal. The book recorded the information about all his teachers that he learned from, until the period of sahabah and tabi'in. Shaykh Akram Muhammad Ziyadah also compiled and translated the books of 
INTERNATIONAL JOURNAL OF ACADEMIC RESEARCH IN BUSINESS AND SOCIAL SCIENCES

Vol. 10, No. 9, 2020, E-ISSN: 2222-6990 @ 2020 HRMARS

al-Tabari's teachers (up to 474 people) in his book Mu'jam Shuyukh al-Tabari. He also narrated alAthar from 7214 teacher amounting to 49000 narrations (Ziyadah, 2001).

Some of his famous teachers include (al-Dhahabi, 1983):

1. Ahmad bin al-Miqdam bin Sulaiman bin al-Ash'ash al-'ljli (253H)

2. Imad bin Mani' al-Bagahawi Abu Ja'far al-'Asam (m. 244H)

3. Ishaq al-Marwazi al-Hafiz (m.254H)

4. Ismail bin Musa al-Farazi Abu Muhammad (254H)

5. Al-Hasan bin Muhammad al-Sabbah al-Za'farani Abu Aliy al-Baghdadi (260H)

6. Al-Rabi' bin Sulayman al-Azdi (256H)

7. Dawud bin Ali al-Asbahani al-Zahiri $(270 \mathrm{H})$

The greatness of al-Tabari in mastering various knowledge made him the reference for many students. His fame caused the students to come from all over the country to learn from him and attend his lectures. That made he had countless number of students. Many of them emerged as imam mujtahid, qadi, and great scholars. Ziyadah (2001) also listed 67 of al-Tabari's famous students in his book entitled Mu'jam Shuyukh al-Tabari, which include (al-Dhahabi, 1983):

1. Ibrahim bin al-Salt al-Dinawari

2. Ahmad bin Ibrahim al-Kindi

3. Ahmad bin Ahmad al-Bazzaz

4. Ahmad bin Ja'far al-Khilal

5. Abu Ja'far Ahmad bin Ali Abi Talib al-Katib

6. Ahmad bin Sulayman al-Jariri

7. Ahmad bin Shu'ayb bin Saleh al-Warraq

\section{Al-tabari's Contribution to Knowledge}

The greatness of al-Tabari in various knowledge is undisputed. This fact is proven by his ability to author a lot of books that each one has dozens of volumes that cover various disciplines. He was also able to write dozens of papers daily up to 40 days and that surpasses the ability of an ordinary person. His love for knowledge made him to devote his life to teaching and learning that he did not manage to think about marriage, and he had spread his knowledge widely. It can be seen in several books of turath such as Tafsir al-Qur'an al-'Azim by Imam Ibn Kathir that narrated the tafsir of al-Tabari a lot. $\mathrm{He}$ also authored many books in various knowledge areas that had been the references for previous scholars and even today, which include Jami' al-Bayan 'an Ta'wil Ayi al-Qur'an, Al-Qira'at wa Tanzil al-Qur'an, Tarikh al-Rusul wa al-Muluk, Tarikh al-Umam wa al-Muluk, Zayl al-Muzil Ikhtilaf al-Fuqaha' fi Kathirin min al-Ahkam al-Shar'iyyah, and Latif al-Qawl fi Ahkam Shara'l' al-Islam (al-Hamawi, 1993).

His books show the greatness of his thought and the rich of the Arab heritage since hundreds of years ago. Even until now his books will be the main reliable and valuable references when it comes to the discipline of Tafsir, Sirah, and Figh Nahw, to name a few (Yusof \& Hisyam, 2015).

\section{The Greatness of al-Tabari and Scholarly Recognition}

The greatness of Imam al-Tabari in the mastery of knowledge has been scholarly recognized among the past and present Muslim scholars. The Muslim scholars have recorded numerous accolades and 
honors for his greatness via their essays and poetries. Imam Yaqut in his book has described Imam al-Tabari as follows (al-Baghdadi, 2001)

He was one of the great scholars whose words were taken as a fatwa, referring to his view of the breadth of knowledge and its advantages. With him all the knowledge where no one was at par in that period. He memorized and know the meanings of al-Qur'an, well-versed about the laws and know the knowledge of Sunnah, words of sahabah ( athar) and the tabi'in who are different in law enforcement. He was also knowledgable in halal and haram and history and human civilization...

He also specialized in other areas such as al-Nahw, al-Lughah, al-'Arud, and al-Qira'at. This was evidenced through his books and recognition from other scholars. For example, Abu Ali Hasan bin 'Ali al-Ahwazi al-Muqri' who narrated eleven qiraat in his book al-Iqna', described Imam al-Tabari as follows:

Abu Ja'far Tabari knew the knowledge of al-Fiqh, al-Hadis, al-Tafsir, al-Nahw, al-Lughah, and alArud. He authored a great piece for each of the knowledge. He had a great book of qiraat where I have seen as much as 18 volumes but in big writing. The book discusses the whole qiraat including mashhur and shadh along with the reasoning and explanation, and from which the mashhur recitation techniques were selected.

Tabari's prowess in knowledge and writing has been recognized by most of the scholars. This fact was supported through some narrations where he had written an average of 40 sheets of paper every day in 40 years.

\section{Al-tabari Expertise in the Knowledge of Qiraat}

Qiraat is linguistically known as the plural of Qiraah reading or recitation. Qiraat are inclusive of all words in the words in the Quraan, either those Qiraat agreed upon by scholars or those on which there is dispute (Abdelgelil, 2020).

Among the greatness of al-Tabari in the mastery of knowledge is his beautiful recitation of al-Qur'an and his expertise in qiraat. Abu Bakr Ibn Mujahid praised him in his book, "I have never heard anyone in the mihrab with a better recitation of Abi Ja'far." There was another narration al-Khatib alBaghdadi from Abu Qasim al-Azhari from Abu Hassan bin Rizqawayh from Abi Ali al-Tumari about ibn Mujahid's recognition when he heard the recitation of al-Tabari during prayer (Ibn Kathir, 2005) "Indeed, I do not feel that God will make someone who recites qiraat better than this (man)."

The recognition by Ibn Mujahid, from baghdad a well-known Qurra', expert in qiraat and the first who collected and wrote qiraat sab'ah in his book al-Sab'ah fil al-Qiraat (Razali, 2009) during the 4th century against al-Tabari is enough to describe his greatness in the knowledge of qiraat.

\section{Expert in Qiraat Via Writing}

His books in the knowledge of qiraat are highly recognized among the Muslim scholars. His books have been referred to until today and they include:

\section{Kitab al-Qira'at wa Tanzil al-Qur'an.}

This book discusses the whole qiraat including mashhur and shadh along with the reasoning and explanation, and from which the mashhur recitation techniques were selected (al-Baghdadi, 2001). 
INTERNATIONAL JOURNAL OF ACADEMIC RESEARCH IN BUSINESS AND SOCIAL SCIENCES Vol. 10, No. 9, 2020, E-ISSN: 2222-6990 @ 2020 HRMARS

\section{2. al-Fasl bayna al-Qira'at.}

This book generally explains the differences between the qurra reagarding the huruf of al-Qur'an in reference to the qurra from Makkah, Madinah, Kufah, Basrah, Sham, and a few others. He differentiated every recitation by mentioning its wajh, definition, and dalil for each recitation based on its tafsir and icrab (al-Hamawi,1993).

\section{Jami' al-Bayan 'an Ta'wil Ay al-Qur'an}

Al-Tabari was among the first scholars who debated the tafsir of al-Qur'an in the sequence of surah, verse and managed to finish the tafsir of the whole 30 juzuk of al-Qur'an in 8 years. It was written in imla'i by his companions (al-Khatib, 2001). The greatness of this book can be seen from the method of the discussion:

a. Scrutinizing the debate of qiraat while interpreting verses with khilaf in qiraat

While debating the knowledge of qiraat, al-Tabari brought the wajh of qiraat without relying on any imam of qiraat who were agreed by the qiraat scholars. He subsequently outweighed (tarjih) his preferred wajh of qiraat based on the language of Arabic, qiyas, or ijma ${ }^{c}$ al-Qurra'. He also used the method of tarjih and tafdil between the qiraat of al-Mutawatirah and al-Mashhur, and also claimed that several authentic qiraats are not to be recited especially the wajh of al-Ahadiyyah.

He also brought a few examples of qiraat shadhdhah to justify the interpretation of a verse. For instance, while discussing the meaning of wusta prayer in this verse:

$$
\text { حفظوا على الصلوت والصلوة الوسطى }
$$

Maintain with care the [obligatory] prayers and [in particular] the middle prayer (wusta prayer) and stand before Allah, devoutly obedient.

(al-Baqarah, 238)

He gave the example of qiraat shadhdhah as printed in mushaf 'Aishah to justify the meaning of wusta as Asr prayer:

$$
\text { حافظوا على الصلوات والصلاة الوسطى وهي العصر }
$$

Qiraat shadhdhah was also brought by al-Tabari as comparison or notification that there were scholars who applied the recitation method, and he verified that the method was not accepted as sahih.

b. Discussing specific verses containing khilaf in qiraat on the basis of language (al-Nahw dan alSarf), relying on the mazhabs of Arabic language such as al-Kufiyyun, al-Basriyyun Ahl al-Sham, and Ahl- al-'Iraq.

This method was evidenced when al-Tabari discussed the khilaf of wajh of qiraat in the first verse of surah al-Nisa, specifically on the word (والأرحام). He chosed the recitation with al-Nasb based on the accuracy of Arabic language. He overruled the recitation with l-Khafd as 'ataf towards (ب)) with the reason that the recitation was not parallel to the use of Arabic kalam and only used in the case of darurah al-Shi'r (necessity in poetry) (al-Tabari, nd).

c. Using the method of al-Tarjih towards the wajh of qiraat based on the more valid opinion to him. 
INTERNATIONAL JOURNAL OF ACADEMIC RESEARCH IN BUSINESS AND SOCIAL SCIENCES Vol. 10, No. 9, 2020, E-ISSN: 2222-6990 @ 2020 HRMARS

For example, while discussing the issues of having intercourse with wives at the time of menstruation in this verse:

$$
\text { ولا تقريوهن حتى يطهرن }
$$

And do not approach them until they are pure ...

(al-Baqarah, 222)

al-Tabari presented several narrations and opinions from Salafi scholars on this issue. Several scholars defined the word $\div$ as "the stop of blood flow" on the basis of dammah and takhfif al-Ha' and several others defined as "until they are cleansed" on the basis of tasydid and takhfif al-Ha'.

In this case, al-Tabari chose the second opinion which means "bathing the whole body after the completion of a menstrual cycle", based on the ijma' where it is forbidden for men to have sexual intercourse with their wives at the time of menstruation, until the wives perform the obligatory bathe after the completion of a menstrual cycle.

This method has been the main guideline among the scholars of tafsir, especially Imam Ibn Kathir. In his book entitled Tafsir al-Qur'an al-'Azim, Imam Ibn Kathir used most of the methods and narration from al-Tabari.

\section{Expert in the Narration of Qiraat}

Al-Tabari narrated the knowledge of qiraat from several Qurra'. Originally, he recited al-Qur'an using the qiraat of Hamzah until he chose his own recitation technique. He received the narration of qiraat of Hamzah through two ways (tariq), which are:

1. Tariq Sulayman bin Abd al-Rahman bin Hammad al-Talhi daripada Khallad from Salim bin 'Isa from Hamzah.

2. Tariq Yunus bin Abd al-'A'la daripada Ali bin Kisah from Salim bin 'Isa from Hamzah.

Although he has his own qiraat technique, it was not popular and only a few narrated to us now. Among the narrations were from Abu Hassan al-Juba'i and Shaykh al-Sifr, a qari in Baghdad who narrated from 'Abd al-Hamid bin Bakr from Ibn 'Amir. This happened due to the piety of al-Tabari where he told his students (as narrated by Abu Ali Hasan bin Abu Ali al-Ahwazi) not to attribute his qiraat when he was still alive, except after his death from three imams, including Abu Ali Hasan alAhwazi (al-Hamawi, 1993).

To err is human. Although his mastery in the knowledge of qiraat was recognized by many Muslim scholars, a few of his narrations contain errors. These errors were pointed by Ibn Mujahid while acknowledging the book of qiraat by al-Tabari:

...except I found several errors and he already mentioned them to me, and I was amazed with him despite his mastery of qiraat Hamzah. He mentioned that the errors were due to Abu 'Ubayd bin Qasim bin Salam (the narration of al-Tabari was mostly taken from him). Abu 'Ubayd forgot the wajh and al-Tabari narrated it to him. 
INTERNATIONAL JOURNAL OF ACADEMIC RESEARCH IN BUSINESS AND SOCIAL SCIENCES Vol. 10, No. 9, 2020, E-ISSN: 2222-6990 @ 2020 HRMARS

\section{Conclusion}

Imam al-Tabari was a scholar that contributed so much to the knowledge of Islam. His life was almost entirely devoted to seek and disseminate knowledge for the benefits of the Muslims. He was not only regarded as a mufassirin, but also recognized by Muslim scholars such as Ibn Taymiyyah, Ibn Kathir, Ibn Hajar Al-'Asqalani, Abu Ali Hasan bin Ali al-Ahwazi, and al-Asfaraini, as a respectable imam alQurra' and the expert in the knowledge of qiraat and other fields.

The discussion of qiraat in the tafsir of al-Tabari proves his expertise and significantly contributes to the areas tafsir and qiraat. He was regarged as the pioneer for next mufassirin who properly discussed the knowledge of qiraat in the books of tafsir. His book entitled Jami' al-Bayan 'an Ta'wil Ay al-Qur'an has been the main reference in the study of tafsir and regarded as ummahat alKutub in Islamic studies.

\section{Acknowledgment}

The authors would like to record our appreciation to Universiti Sultan Zainal Abidin (UniSZA), Terengganu for the University's Research Grant Fund (DPU).

\section{Corresponding Author}

Nor Hafizi bin Yusof

Universiti Sultan Zainal Abidin,

Gong Badak Campus, 21300 Kuala Terengganu,

Malaysia.

Email: nhafizi@uniszaedu.my

\section{References}

Al-Jazari, M. S. A. M. (2001). al-Mu'jam al-Saghir li Ruwat al-Imam Ibn Jarir al-Tabari, Dar Ibn Affan, Misr,.

Abdelgelil, M. F. (2020). Types of Qiraat Mentioned in the Book of Mohd A'Tarahim bin Razali 2009. Perkembangan Awal Ilmu Qiraat. Jurnal Islam dan Masyarakat Kontemporari. Terengganu: Penerbit UniSZA

Ahmad, S. (1983), Siyar A'lam al-Nubala', Ed. Akram al-Bushi, Bayrut : Muassasah al-Risalah. Al-'Asqalani, H. A. A. (2002). Lisan al-Mizan. Riyad: .al-Maktabah al-Matbu'ah al-Islamiyyah.

Al-Baghdadi, A. A. B. (2001). Tarikh Baghdad. Ed. Dr. Bisyar 'Awwad, Bayrut: Dar al-Gharab alIslami.

Al-Hamawi, 'A. S. A. A. Y. (n.d.) Mu'jam al-Buldan, Bayrut: Dar al-Sadir,.

Al-Harari , M. M. A.U, (1987). al-Qiraat al-Mutawatirah allati Ankaraha Ibn Jarir al-Tabari fi Tafsirih wa al-Radd 'alayh min Awwal al-Qur'an ila Akhir Surah al-Tawbah.

Al-Khalidi, A. S. A. (2010). Ta'rif al-Darisin bi Manahij al-Mufassirin. Damsyik: Dar al-Qalam. Almustadrak Alaa Al-Sahihain. International Journal of Psychosocial Rehabilitation.

Al-Jazari, M. S. A. M. (n.d). al-Nashrfi al-Qira'at al-Ashr. Ed. Jalal al-Din Muhammad Sharaf. Misr: Dar al-Sahabah

Ibn-Kathir, A. A. A. I. (2005). al-Bidayah wa al-Nihayah. Ter. (Ahmad Nasir Mohd Yusof \& Haris Yunus), cet 1. Kuala Lumpur: Dewan Bahasa dan Pustaka. 
INTERNATIONAL JOURNAL OF ACADEMIC RESEARCH IN BUSINESS AND SOCIAL SCIENCES

Vol. 10, No. 9, 2020, E-ISSN: 2222-6990 @ 2020 HRMARS

Ibn-Khallikan, M. S. A. (n.d.) Wafayat al-A'yanWa Anba' Abna'al-Zaman, ed. Dr. Ihsan Abbas, Dar al-Sadir Bayrut.

Yusof, N. H. (2015). Ketokohan al-Tabari Dalam Ilmu Qiraat dan Pandangan Beliau Terhadap AlAhruf Al-Sab'ah. Jurnal Islam dan Masyarakat Kontemporari. Terengganu: Penerbit UniSZA. Ziyadah, A. M. (2001). Mu'jam Shuyukh al-Tabari, Misr: ,Dar Ibn Affan. 